\title{
THEORETICAL AND METHODOLOGICAL APPROACHES ON THE INTELLECTUAL CAPITAL
}

\author{
Alexandra Ioana Daniela Rus \\ “Babeș-Bolyai” University, Cluj-Napoca, Romania, e-mail: rusalexandra04@yahoo.com \\ Monica Violeta Achim* \\ “Babeș-Bolyai” University, Cluj-Napoca, Romania, e-mail: monica.achim@econ.ubbcluj.ro \\ Sorin Nicolae Borlea \\ “Vasile Goldiș” Western University of Arad, Romania, e-mail: snborlea@yahoo.com
}

(Received: December 2018; Accepted: March 2019; Published: June 2019)

\begin{abstract}
The aim of this paper consists in providing a general overview of the notion of intellectual capital as a key to maximizing the corporate performance. Following the researches carried out, we present the delimitations of the intellectual capital in relation with human capital, relational capital and structural capital. In terms of its measurement, we focus on a question which could be a solid base for the next studies: "Can intellectual capital be evaluated?" In this regard, a number of methods (direct and methods based on assets returns), generic model and individual company models were presented, concluding in this way with a hierarchy in terms of utility and their importance.
\end{abstract}

Key words: intellectual capital, performance, company's performance

JEL Codes: O34.

\section{Introduction}

As we know, the intellectual capital is one of the most important pieces within an organization, being a key in its function. Analyzing the research literature and combining analysis with synthesis, we found that intellectual has a lot of definitions, which consist in a lot of component elements related to human capital,

\footnotetext{
* Corresponding author: Monica Violeta Achim.E-mail: monica.achim@econ.ubbcluj.ro
} 
Rus, A.I.D., Achim, M.V., Borlea, S.N., (2019)

Theoretical and methodological approaches on the intellectual capital

relational capital and structural capital. Moreover, the way of intellectual capital assessment raises a lot of questionable measurements.

Starting from these premises and from the central focus of the paper, firstly, we intend to present the notion of intellectual capital as a key in the corporate functioning and performance of companies by presenting a multitude of valences assigned to it. Secondly, in order to answer to a question which referees to the measurement of the intellectual capital, we present the most important measures of this "key", which are direct methods, methods based on return assets and individual company models.

Our main contribution to previous work consists in finding the gap of the literature and this we think that could be the fact that, this notion has a lot of meanings, but the big major refers to: experience, knowledge, skills, intangible assets etc.

The remainder of the paper is organized as follows: in the section 2 the definitions of intellectual capital are reported along with a critical analysis; section 3 reveal the structural dimensioning of the intellectual capital; section 4 emphasizes the measures of intellectual capital; finally, the last section presents the conclusions.

\section{Methodology}

In order to make this and present the methodological and theoretical approaches, we have made a research of the literature already presented to try to understand and also to present the notion of the intellectual capital. We kept the most important definitions given, and in order to answer to the question if the intellectual capital can be measured we try to investigate if there are methods which can help us. Also we would like to see if this is composed by others elements and we find out some classifications.

\section{Defining the intellectual capital-theoretical approaches}

The concept of intellectual capital was defined and argued for the first time by Thomas A. Steward, one of the editors of the famous American magazine Fortune. Basically, it is the sum of what every employee knows in a company and can be used to develop his competitive capacity (Steward, 1999).

Unlike the elements that operate in the field of accounting, namely: equipment, buildings, machinery etc., and the intellectual capital does not dress a material form, being defined in most cases as an intangible asset. Thus, in order to express and understand this notion better, the need for defining intangible assets can be observed. This type of asset represents entity-controlled resources that are not of a physical nature, are capable of delivering future economic benefits, are legally protected and cannot be reliably evaluated, being considered the most criticized resources of an entity, not defined in clear and precise terms by most entities (Andreou et al., 2007, 52).

2 Ssciendo

Studia Universitatis "Vasile Goldis" Arad. Economics Series Vol 29 Issue 2/2019 ISSN: 1584-2339; (online) ISSN: 2285 - 3065

Web: publicatii.uvvg.ro/index.php/studiaeconomia. Pages $1-16$ 
Rus, A.I.D., Achim, M.V., Borlea, S.N., (2019)

Theoretical and methodological approaches on the intellectual capital

Relevant literature shows a wide range of definitions assigned to intellectual capital, but so far specialists have not agreed upon a general, valid definition that can be assigned to this concept. In the literature, it is indicated that there is a wide range of definitions attributed to intellectual capital, but even so far the specialists did not agree with a generally valid definition that can be attributed to this concept.

Table 1. Definitions of Intellectual Capital

\begin{tabular}{|c|c|c|}
\hline Author & Year & Definition \\
\hline Becker G. & 1964 & $\begin{array}{l}\text { Investing in human capital, as well as preparing } \\
\text { the individual }\end{array}$ \\
\hline Itami H. & 1987 & $\begin{array}{l}\text { Intangible assets in the form of information- } \\
\text { based assets that include technology, customer } \\
\text { loyalty, entity image, organizational culture, } \\
\text { management skills are the most important } \\
\text { rewards for achieving long-term business } \\
\text { success. }\end{array}$ \\
\hline Hall R. & 1989 & $\begin{array}{l}\text { Intellectual assets including proprietary patent, } \\
\text { trademark, copyrights, reputation, knowledge, } \\
\text { experience, and employee skills. }\end{array}$ \\
\hline Brooking A. & 1996 & $\begin{array}{l}\text { Combination of four main active market } \\
\text { components, assets centered on human } \\
\text { resources, intellectual property and infrastructure } \\
\text { assets that enable entities to operate. }\end{array}$ \\
\hline Edvinsson L., Malone M.S. & 1997 & $\begin{array}{l}\text { Possession of knowledge, experience, } \\
\text { organizational technology, customer relations, } \\
\text { professional skills that offer competitive } \\
\text { advantages to the market. }\end{array}$ \\
\hline Stewart T.A. & 1998 & $\begin{array}{l}\text { Intellectual matter that refers to knowledge, } \\
\text { information, intellectual property, experience } \\
\text { and that creates wealth }\end{array}$ \\
\hline $\begin{array}{l}\text { Bontis N., Dragonetti N.C., } \\
\text { Jacobson K., Roos G. }\end{array}$ & 1999 & $\begin{array}{l}\text { A collection of intangible resources that refers to } \\
\text { any value generating factor within an entity. }\end{array}$ \\
\hline Sullivan P.H. & 2000 & Knowledge that can be converted into profit \\
\hline $\begin{array}{l}\text { Bukh P.N., Laresen H.T., } \\
\text { Mouritsen J. }\end{array}$ & 2001 & $\begin{array}{l}\text { Intellectual capital refers not only to a single } \\
\text { component, it is fragile and needs to be } \\
\text { approached as a whole set of component } \\
\text { elements }\end{array}$ \\
\hline Petty R., Guthrie J. & 2002 & $\begin{array}{l}\text { The economic value generated by two intangible } \\
\text { asset classes of an entity (organizational capital } \\
\text { and human capital) }\end{array}$ \\
\hline $\begin{array}{l}\text { Mouritsen J., Bukh P.N., } \\
\text { Laresen H.T., Johanesen M.R. }\end{array}$ & 2004 & $\begin{array}{l}\text { The set of elements such as employees, } \\
\text { customers, IT, management and knowledge. }\end{array}$ \\
\hline
\end{tabular}


Rus, A.I.D., Achim, M.V., Borlea, S.N., (2019)

Theoretical and methodological approaches on the intellectual capital

\begin{tabular}{|c|c|c|}
\hline Fustec A., Marois B. & 2006 & $\begin{array}{l}\text { Intangible capital is the wealth of an entity, } \\
\text { reflected in its financial statements. }\end{array}$ \\
\hline Ricceri F. & 2008 & $\begin{array}{l}\text { Intellectual resources or knowledge - based } \\
\text { resources of an entity. }\end{array}$ \\
\hline $\begin{array}{l}\text { Sharabati et al., Krstić \& } \\
\text { Bonić, } 2016\end{array}$ & $\begin{array}{l}2010 / \\
2016\end{array}$ & $\begin{array}{l}\text { "Intellectual capital consists of those elements of } \\
\text { intangible assets that explain the difference } \\
\text { between a company's market value and its net } \\
\text { book value. It is appreciated as the "excess" of } \\
\text { the recognized market value above the } \\
\text { company's book value" }\end{array}$ \\
\hline $\begin{array}{l}\text { Ting \& Lean; Amin \& Aslam, } \\
\text { 2017; Pereira-Rodrigues \& } \\
\text { Santos-Rodrigues }\end{array}$ & $\begin{array}{l}2009 / \\
2017\end{array}$ & $\begin{array}{l}\text { "represents the total knowledge, abilities and } \\
\text { experience of the human resource and exploited } \\
\text { by the firm in accordance with its organizational, } \\
\text { internal and external structure" }\end{array}$ \\
\hline Chizari et al., & 2016 & $\begin{array}{l}\text { "Intellectual capital is a form of knowledge that } \\
\text { creates competitive advantage and displays the } \\
\text { intangible value of a company" }\end{array}$ \\
\hline
\end{tabular}

Source: authors' view

After presenting these definitions offered by the specialists in this field, it is imperative to remember the most comprehensive definition given to the intellectual capital given by CIMA (Institute of Management Accountants) (2001), which states the following: "Intellectual capital is possession of knowledge and experience, skills and professional qualifications, good relationships, technological capabilities that, when applied, offer entities competitive advantages. "Another important definition is given by the OECD, namely: "The economic value of two intangible elements of an entity - organizational capital and human capital." IFAC (International Federation of Accountants) (1998) also defines capital as "the total capital or capital stock based on the entity's knowledge".

Even if it not a clear definition, the remark made by Dessler (2013), which says that the organizations could never operate without the fundamental factor of human resources and the production factor, because human resources management can help in order to ensure that we get results through people is a good one because here is showed up the an important element retrieved in a lots of definitions (Németh Z et.al., 2016).

Thus, we note that there is no unanimously accepted definition by all specialists, but most of them present intellectual capital as a non-monetary element, and within all definitions refer toknowledge, capacities, abilities, experience, intangible assets, value intangible, all of which are elements that give value to the company.

\footnotetext{
4 Studia Universitatis "Vasile Goldis" Arad. Economics Series Vol 29 Issue 2/2019 $\checkmark$ sciendo ISSN: 1584-2339; (online) ISSN: $2285-3065$

Web: publicatii.uvvg.ro/index.php/studiaeconomia. Pages $1-16$
} 
Rus, A.I.D., Achim, M.V., Borlea, S.N., (2019)

Theoretical and methodological approaches on the intellectual capital

\section{The structural dimensioning of the intellectual capital}

Due to the fact that many papers based on this notion have been elaborated in the literature, very ample because of the fact that there is no generally accepted taxonomy of the intellectual capital, and as far as its structural framework is concerned, there are several perceptions regarding its classification.

The first author who proposed a classification of intellectual capital was Karl Erik Sveiby in 1997 from a non-accounting perspective, dividing it into three broad categories: Employee competences, internal structure and external structure. Following Sveiby (1997), Edvinsson (1997), Bontis (1998) and Stewart (1998) adopt the initial proposed classification by Sveiby (1997) but rename the components as human capital, organizational capital and customer capital (Choong, 2008).

In current literature, intellectual capital is divided into three components: (1) Structural or internal capital, (2) Relational or external capital, and (3) Human capital.

- According to CIMA and in line with the views and studies conducted by researchers from different universities in Europe, known as the Meritum Project name, human capital is defined as the total knowledge, skills and experience that employees take with them at the time in which he leaves. Some of this knowledge is unique to each individual, others may be generic. Examples of this can be provided: innovative capacity, creativity, know-how and past experiences, team work capacity, employee flexibility, and tolerance for ambiguity, motivation, satisfaction, learning capacity, loyalty, formal training and education.

- Relational capital is defined as the total resources anchored in the company's external relations with different suppliers, partners in the research and development domain, it includes that part of the human and structural capital involved in the company's relations with the stakeholders, namely investors, creditors, suppliers and also the perception that they have on the company. Some examples in this sense can be: image, customer loyalty, customer satisfaction, links with suppliers, commercial power, negotiating capacity with financial entities and environmental activities.

- Structural capital is defined as the total knowledge remaining within the firm. It includes organizational routines, procedures, systems, culture, and databases.

- Some examples can be: organizational flexibility, documentation service, the existence of a knowledge center, the general use of a knowledge center, the general use of information technology and organizational learning 
Rus, A.I.D., Achim, M.V., Borlea, S.N., (2019)

Theoretical and methodological approaches on the intellectual capital

capacity. Some of these may be legally protected and become intellectual property rights, legally owned by the company under separate title.

According to the market value scheme, Edvinsson (1997) divides intellectual capital into two components: human and structural capital, with structural capital being branched into capital-customers and organization, which in turn is made up of innovation and process capital; and ultimately the innovative capital is presented as being made up of intellectual property and intangible resources.

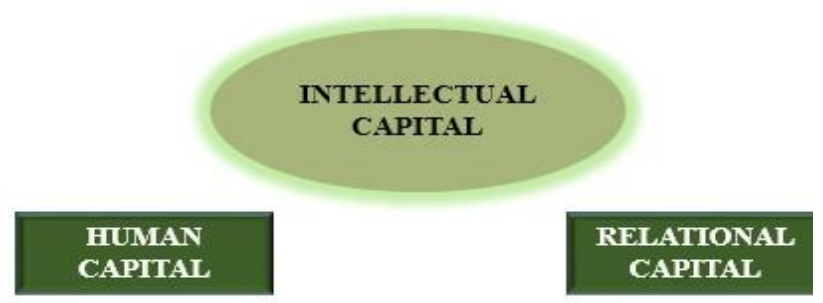

\section{STRUCTURAL}

CAPITAL

Figure 1. Classification of intellectual capital

Source: authors view

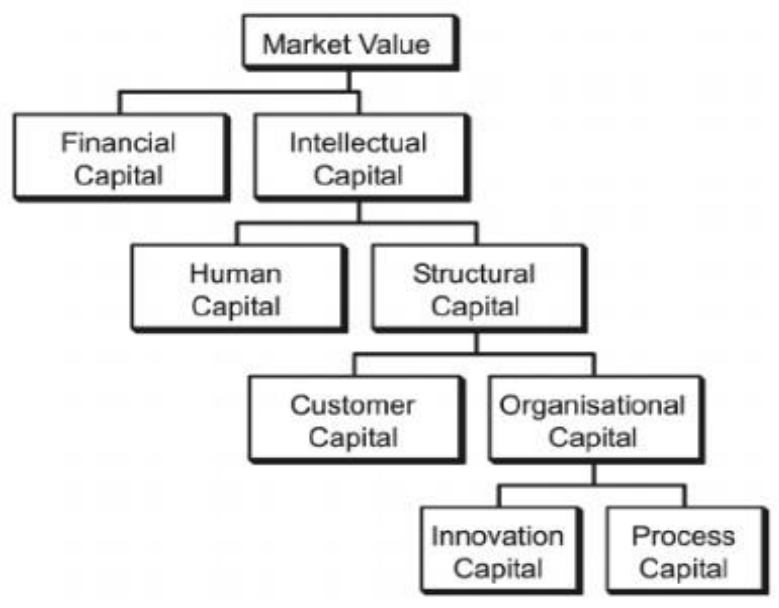

Figure 2. Classification of intellectual capital Source: Edvinsson (1997) 
Rus, A.I.D., Achim, M.V., Borlea, S.N., (2019)

Theoretical and methodological approaches on the intellectual capital

As we mentioned earlier that International Federation of Accountants offers a different definition, the same body also offers a slightly different classification of intellectual capital.

Table 2. Classification of Intellectual Capital by International Federation of Accountants

\begin{tabular}{llll}
\hline Human capital & \multicolumn{1}{c}{$\begin{array}{c}\text { Relational } \\
\text { (Customer) } \\
\text { Capital }\end{array}$} & \multicolumn{1}{c}{$\begin{array}{c}\text { Oganisational Structural } \\
\text { Capital }\end{array}$} \\
\hline Know-how & Brands & $\begin{array}{c}\text { Intellectual } \\
\text { property }\end{array}$ & $\begin{array}{c}\text { Infrastructure } \\
\text { assets }\end{array}$ \\
\hline Education & Customers & Copyrights & $\begin{array}{l}\text { Management } \\
\text { philosophy }\end{array}$ \\
\hline Vocational qualification & Customer loyalty & Design rights & $\begin{array}{l}\text { Management } \\
\text { processes }\end{array}$ \\
\hline Work-related knowledge & Company names & Trade secrets & $\begin{array}{l}\text { Information } \\
\text { system }\end{array}$ \\
\hline Occupational assessments & Backlog orders & Trademarks & $\begin{array}{l}\text { Networking } \\
\text { system }\end{array}$ \\
\hline Work-related compenecies & $\begin{array}{l}\text { Distribution } \\
\text { channels }\end{array}$ & Service marks & $\begin{array}{l}\text { Financial } \\
\text { relations }\end{array}$ \\
\hline $\begin{array}{l}\text { Entrepreneurial, } \\
\text { innovativeness, proactive and } \\
\text { reactive abilities, changeability }\end{array}$ & $\begin{array}{l}\text { Business } \\
\text { collaboration }\end{array}$ & & \\
& $\begin{array}{l}\text { Licensing } \\
\text { agreements }\end{array}$ & & \\
\hline & $\begin{array}{l}\text { Favorable } \\
\text { contracts }\end{array}$ & & \\
\hline & $\begin{array}{l}\text { Franchising } \\
\text { agreements }\end{array}$ & & \\
\hline & Source: International Federation of Accountants, 1998 &
\end{tabular}

Although we observe that some authors (Edvinsson \& Malone, 1997, Stewart, 1997, Canibano et al., 2000, Bontis, 2002) provide different definitions associated with the concept of intellectual capital, the same components of intellectual capital are presented: knowledge, professional skills, experiences and creativity, structural capital refers to intellectual assets and organizational processes, and ultimately to relational capital that relates to relationships with suppliers and customers and also to market knowledge. 
Rus, A.I.D., Achim, M.V., Borlea, S.N., (2019)

Theoretical and methodological approaches on the intellectual capital

\section{The measurement of intellectual capital}

As we know, the intellectual capital is very hard to being measured. And this happens because we think that the quality is harder to measure than the quantity. Even this, we found out that there are some methods and model which helps us to quantify this concept. There are two types of methods: direct methods and methods based on return on assets. And there are also some models which helps us, namely: generic models and individuals company models.

\subsection{Direct methods of measuring the intellectual capital}

There are two most important direct methods of measuring the intellectual capital: Citation- Weightedeva Patents Method and Technology Broker Method, which are presented as following:

a) Citation- Weightedeva Patents Method (CWP)

In order to measure intellectual capital through this method, Gordon Petrash proposed six steps:

- Defining the role of knowledge in business;

- Evaluating all of these assets in order to store, develop, sell or abandon them;

- Linking company strategies to developing knowledge assets;

- Allocation of investments in areas with significant gaps;

- Redefining the asset portfolio and then restoring the cycle composed of the six steps mentioned.

This method identifies the impact of R \& D expenditures on the creation and development of intellectual capital using several indicators, such as: the share of development spending in turnover, income related to $\mathrm{R} \& \mathrm{D}$ expenditure, cost maintenance of a complainant in relation to turnover, etc.

b) Technology Broker Method

This method determines a final indicator that expresses the value of intellectual capital in a monetary expression, starting from the idea that it has four components, namely: market assets, assets centered on the human factor, assets that are part of the intellectual property and assets related to infrastructure. As far as the operation of this method is concerned, it starts with a 20 -question test that aims to increase the value of intellectual capital. The method also uses a number of similar audit questionnaires to examine the value of intellectual capital components. Annie Brooking proposes the following models:

- cost approach;

- market approach;

- income approach. 
Rus, A.I.D., Achim, M.V., Borlea, S.N., (2019)

\subsection{Methods based on return on assets}

The methods based on return on assets are very useful in order to measure the company's performance. In other words, its indicates how well a company is performing by comparing the profit it's generating to the capital it's invested in assets. We have presented the most important methods based on return on assets:

a) Economic Value Added

The Economic Value Added has the role to measure the financial performance achieved by a company and it is determined as a difference between the net operating profit after taxes and the total cost of the invested capital. EVA is one of the most appreciated indicators regarding the achievement of the performance that involves all used resources, indicator that can be adopted for the decentralization of the management decision. (Trandafir, 2015).

EVA $=$ Net operating profit after taxes $-($ Invested capital $\mathrm{x}$ Cost of the invested capital)

b) MVA - Market Value Added

Market Value represents the sum of market value of debt and market value of equity, and capital employed or invested is the sum of equity and debt capital of the company. Market Value Added is the difference between Market Value of Equity and Book Value of Equity.

Market Value Added = Market Value Added of Equity - Book Value Equity.

\subsection{Generic Models}

In addition to the methods, there are some models for measuring the intellectual capital, where are measured the intangible activities, and these models are named generic models and they are presented as follow:

a) Balanced Scorecard

In 1992, Robert Kaplan and David Norton pioneered this model called Balanced Scorecard. Since then, it has become a model for several reporting systems that include non-financial measures. In the last decade, this model has evolved greatly beyond the limits of being a simple measurement framework, becoming a true tool to implement the strategy. It is a set of a cause - effect relationship between production and performance measures and which lead to four perspectives, which we will illustrate in the following table: 
Rus, A.I.D., Achim, M.V., Borlea, S.N., (2019)

Theoretical and methodological approaches on the intellectual capital

\begin{tabular}{|c|c|c|}
\hline \multicolumn{3}{|c|}{ Table 3. Balanced Scorecard } \\
\hline Type of measures & Cause effect-questions & Examples \\
\hline Financial measures & $\begin{array}{l}\text { How do we look to } \\
\text { shareholders? }\end{array}$ & Cash-flow \& profitability \\
\hline Customer measures & $\begin{array}{l}\text { How do our customers } \\
\text { see us? }\end{array}$ & $\begin{array}{l}\text { Price as compared with competitors } \\
\& \text { product ratings }\end{array}$ \\
\hline $\begin{array}{l}\text { Internal process } \\
\text { measure }\end{array}$ & What must we excel at? & $\begin{array}{l}\text { Length of cycle times \& level of } \\
\text { waste }\end{array}$ \\
\hline $\begin{array}{l}\text { Learning and growth } \\
\text { measures }\end{array}$ & $\begin{array}{l}\text { Can we improve and } \\
\text { create value? }\end{array}$ & $\begin{array}{l}\text { Percentage of sales derived from } \\
\text { new products }\end{array}$ \\
\hline
\end{tabular}

Nowadays, Kaplan and Norton underline the importance of visualizing causal relationships of measures and objectives in "Starter Maps." These are essential communication tools that visualize the organization's strategy and also address the processes and systems that need to be implemented.

b) Performance Prism

The Performance Prism is considered to be a second-generation performance measurement and management approach which is developed by Cranfield School of Management in collaboration with consultancy Accenture. This method recognizes the importance of companies taking a holistic approach to stakeholder management in the present culture of involvement. Being an important model, its advantages are: addresses to all stakeholders-not only to investors, also addresses to intermediaries, employees, suppliers, regulators and communities. The model makes this possible in two ways: first, considering that the requirements of those stakeholders and, uniquely, what the organization wants from its stakeholders. Making this possible, the reciprocal relationship and the exchange process with each stakeholder is examined. The flexibility of this model, allows it to be applied to any organizational component. 


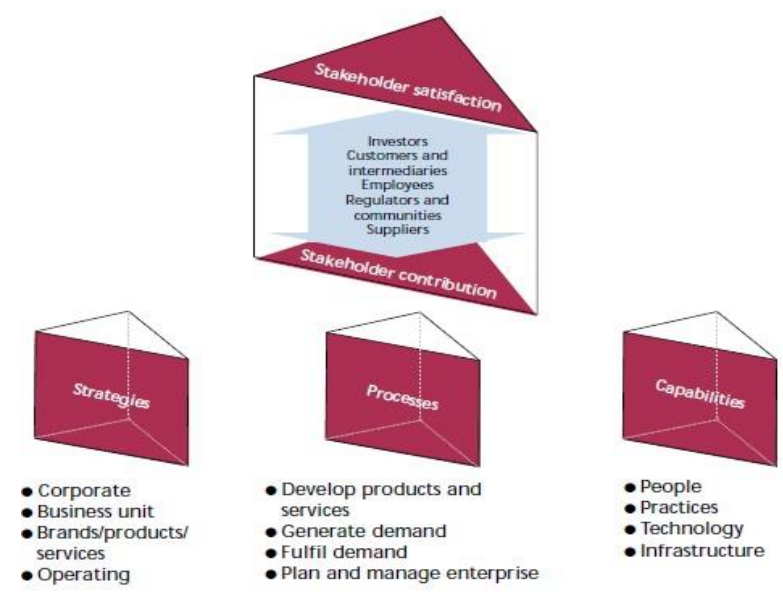

Figure 3. Performance Prism

Source: Starovic and Marr (2004)

c) Knowledge assets map approach

This model was designed to help companies identify and measure their knowledgebased assets and their contribution to the value. The knowledge assets are identified as the sum of two elements: stakeholders and structural - both are organizational resources. The distinction made, reflects the two key components of any enterprise: its actors (internal or external) and its constituent parts, or the elements at the basis of an organization process.

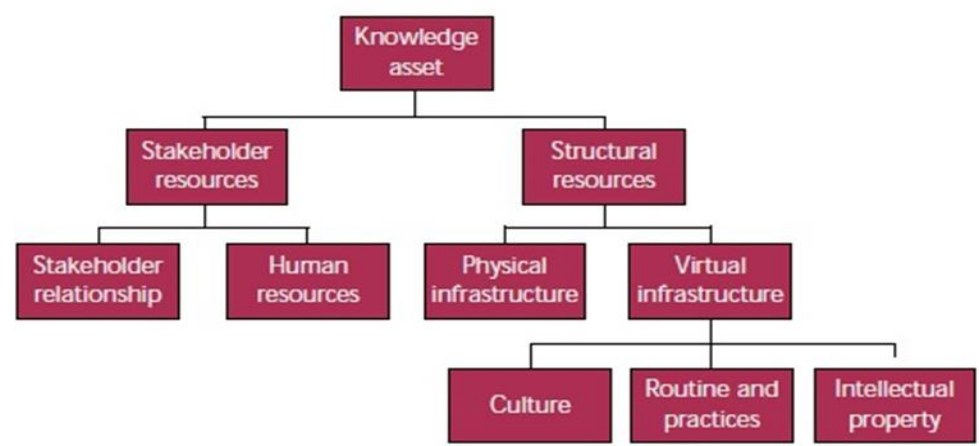

Figure 4. Knowledge assets map approach Source: Starovic and Marr (2004) 
Rus, A.I.D., Achim, M.V., Borlea, S.N., (2019)

Theoretical and methodological approaches on the intellectual capital

\subsection{Individual company models}

a) Skandia Navigator

This individual company model is probably the best known, because it reflects four key dimensions of its business: financial focus, customer focus, renewal and development focus. In the middle of this model it is situated the human focus, which can be named the motor of it, because its drives the whole model. Sveiby (1997) sees the Skandia Navigator as a combination of the BSC and Celemi's intangible assets monitors, another specialist says that it can be "viewed as a house".

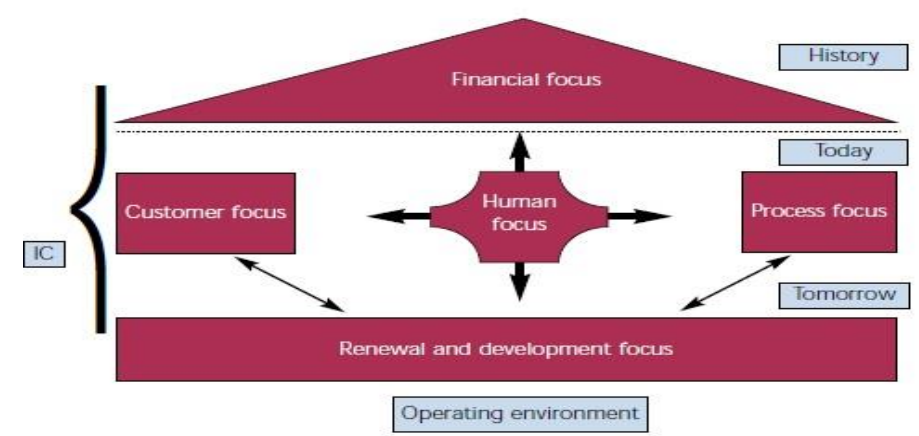

Figure 5. Skandia Navigator

Source: Chartered of Institute of Accountants

b) Ericsson's cockpit communicator

This model is based on the balanced scorecard and five similar perspectives: innovation, employees, process, customers and financial. According to Ericsson, the aims of this product are:

$>$ A vision-driven organization, where priority is given to actions that are compatible with the company's strategies;

$>$ A communicated strategy linked to indicators and actions;

$>$ A balance focus on past, present and future performance;

$>$ A balance between short-term results and long-term strategy;

$>$ The ability to evaluate and change organizational strategy rapidly in line with performance and changing business conditions;

$>$ The ability to manage, to measure and to communicate future values.

b) Celemi's intangible assets monitor

This model is based on three overall categories: customers - external structure, people - competence and organization - internal structure. After these 
Rus, A.I.D., Achim, M.V., Borlea, S.N., (2019)

Theoretical and methodological approaches on the intellectual capital

interdependent categories, the three key areas of growth / renewal, efficiency and stability are tracked, each with its own performance indicators.

Table 4. Celemi's intangible assets monitor

\begin{tabular}{|c|c|c|}
\hline $\begin{array}{l}\text { Our customers } \\
\text { (external structure) }\end{array}$ & $\begin{array}{l}\text { Our structure } \\
\text { (internal structure) }\end{array}$ & $\begin{array}{l}\text { Our people } \\
\text { (competence }\end{array}$ \\
\hline $\begin{array}{l}\text { Growth/renewal } \\
\text { Revenue growth }\end{array}$ & $\begin{array}{l}\text { Growth/renewal } \\
\text { Organisation-enhancing } \\
\text { customers }\end{array}$ & $\begin{array}{l}\text { Growth/renewal } \\
\text { Average professional } \\
\text { competence years }\end{array}$ \\
\hline Image-enhancing customers & $\begin{array}{l}\text { Revenues from new products } \\
\text { R\&D revenues } \\
\text { Intangible investments (\% value added) }\end{array}$ & $\begin{array}{l}\text { Competence- } \\
\text { enhancing } \\
\text { Customers } \\
\text { Growth in } \\
\text { professional } \\
\text { Competence } \\
\text { Experts with post- secondary degree }\end{array}$ \\
\hline $\begin{array}{l}\text { Efficiency } \\
\text { Revenues per customer }\end{array}$ & $\begin{array}{l}\text { Efficiency } \\
\text { Proportion admin staff expert } \\
\text { Revenues per admin staff }\end{array}$ & $\begin{array}{l}\text { Efficiency } \\
\text { Value added per } \\
\text { Expert } \\
\text { Value added per employee }\end{array}$ \\
\hline $\begin{array}{l}\text { Stability } \\
\text { Customer satisfaction index } \\
\text { Repeat orders } \\
\text { Five largest customers }\end{array}$ & $\begin{array}{l}\text { Stability } \\
\text { Admin staff turnover } \\
\text { Admin staff seniority } \\
\text { (years) } \\
\text { Rookie ratio }\end{array}$ & $\begin{array}{l}\text { Stability } \\
\text { People satisfaction } \\
\text { Index } \\
\text { Median age of all } \\
\text { Expert seniority } \\
\text { (years) } \\
\text { Expert turnover }\end{array}$ \\
\hline
\end{tabular}

Source : authors work after "Uncovering Hidden Assets”, Celemi Annual Report, 1999

c) Ramboll's holistic company model

This model is structured in a set of keys areas within which certain performance indicators are managed. The keys lead to three sets of results: customer, employee and societal, and all of them combined are making financial results. The key areas are showed in the following figure:

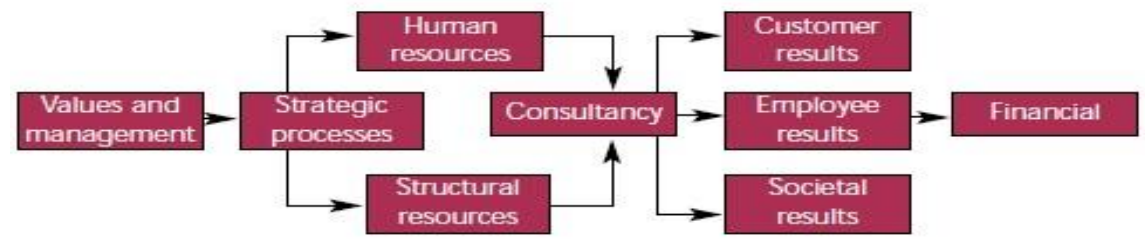

Figure 6. Ramboll's holistic company model

Source: Starovic and Marr (2004)

d) Bates Gruppen Company IQ measurement system

S sciendo Studia Universitatis "Vasile Goldis" Arad. Economics Series Vol 29 Issue 2/2019 
Rus, A.I.D., Achim, M.V., Borlea, S.N., (2019)

Theoretical and methodological approaches on the intellectual capital

This model is structured into four stages, where the Company IQ allows a company to score its knowledge assets against those of similar organization.

- Stage one - identify why the customers buy from the analyzed company and not from a rival

- Stage two - identify the intellectual assets that produce star attributes

- Stage three - in this stage it is calculated the Company'IQ

In terms of measurement methods and models, we believe that all are important because we are able to measure intellectual capital through them, a concept so difficult to quantify. By analyzing all the methods, the respective models, we cannot compare them, given that they use different elements in measuring it. However, we believe that, from the point of view of the models, Skandia Navigator combines the most distinct categories of distinct elements being the best in order to quantify the intellectual capital, with the main focus "Human focus".

\section{Conclusions}

Intellectual capital is an important pawn in the organization and in society. It can be a very important source of competitive advantage for business which can stimulate innovation that leads to wealth generation.

Regarding to the definition of intellectual capital, there is no unanimously accepted definition from all the specialists, but many of them to other notions like: knowledge, abilities, skills, experience, intangible assets, intangible value, and all of these are elements which give value to the company and in this way we presented the most 16 definitions given to the intellectual capital by the specialists in the field, but we think that there is a very comprehensive one given by CIMA in 2001, which reunite all of the characteristics of the intellectual capital.

In what classification is concerned, there are two big categories but the general one is that intellectual capital is divided into: human capital, structural capital and relational capital. Even if there are many opinions like, measuring the intellectual capital is very hard, because there are not existing a lot of quantitative elements and also that we think measuring quality is harder than the quantity, we also find out that there are methods based on return on assets which are very useful in order to measure the company's performance and the most important methods are: Economic Value Added and Marker Value Added. In what concern the other methods based on measuring the quality, we can say that there is a lot which can help us. And they are presented being direct methods which are: CitationWeightedeva Patents Method and Technology Broker Method. Also, we find out that in addition to the methods, there are some models, named Generic Models structured in: Balanced Scored-Card, Performance Prism, Knowledge assets map approach. For helping every company in particularly exist Individual company models too: Skandia Navigator, Ericsson's cockpit communicator, Celemi's 
Rus, A.I.D., Achim, M.V., Borlea, S.N., (2019)

Theoretical and methodological approaches on the intellectual capital

intangible assets monitor, Ramboll's holistic company model and Bates Gruppen Company IQ measurement system. In terms of measurement methods and models, we believe that every method and model is very important because in this way we are able to measure intellectual capital through them, a concept so difficult to quantify.

\section{Acknowledgements}

The authors thank the anonymous reviewers and editor for their valuable contribution.

\section{Funding}

This research received no specific grant from any funding agency in the public, commercial, or not - for - profit sectors.

\section{Author Contributions}

AIDR was responsible for the literature review and the way to perform the relation between analysis and synthesis of the ideas. MVA was responsible for the idea of the paper and the overall design of the study. SNB was responsible for the relation between theory and practice and implementing theoretical approach of the capital intellectual in the business environment.

\section{Disclosure Statement}

The authors have not any competing financial, professional, or personal interests from other parties.

\section{References}

1. Andreou, N.A., Green, A., Stankosky, M., (2007), A framework of intangible valuation areas and antecedents, Journal of Intellectual Capital, vol. 8, no. 1, pp. 52-75

2. Becker, G., (1964), Human Capital, Chicago, University of Chicago Press

3. Brooking, A., (1997), The management of intellectual capital, Long Range Planning, Vol. 30, No. 3, pp. 364-365

4. Celemi (1999). Uncovering Hidden Assets, Celemi Annual Report, available: www.celemi.com

5. Cañibano, L., Garcia-Ayuso, M., Sánchez, P., (2000) Accounting for intangibles: a literature review, Journal of Accounting Literature, Vol. 19, pp. 102-130

6. Choong, K.K., (2008), Intellectual capital: definitions, categorization and reporting models, Journal of Intellectual Capital, vol. 9, no. 4, pp. 609-638

7. Chizari, M.H., Mehrjardi, R.Z., Sadrabadi, M.M., Mehrjardi, F.K., (2016), The Impact of Intellectual Capitals of Pharmaceutical Companies Listed in Tehran 
Rus, A.I.D., Achim, M.V., Borlea, S.N., (2019)

Theoretical and methodological approaches on the intellectual capital

Stock Exchange on their Market Performance, Procedia Economics and Finance, 36, pp. 291-300

8. Dessler, G., (2013), Human Resource Management, Pearson Education, 718

9. Edvinsson, L., Malone, M.S., (1997), Intellectual Capital: Realizing Your Company's True Value by Finding Its Hidden Brainpower, Harper Collins Publishers, New York

10. Guthrie, J., Petty, R., Yongvanich, K., Ricceri, F., (2004), Using content analysis as a research method to inquire into intellectual capital reporting, Journal of Human Resource Costing \& Accounting, vol. 5, no. 2, pp. 282-293

11. Itami, H., (1987), Mobilizing Invisible Assets, Harvard University Press, London

12. Larsen, H.T., Mouritsen, J., Bukh, P.N.D., (1999), Intellectual capital statements and knowledge management: measuring, reporting and acting, Australian Accounting Review, vol. 9, no. 3, pp. 15-26

13. Nemeth, Z., Dajnoki K., Suto D., Fenyves V., (2016), Examination of performance management targets in case of an international corporation's Eastern Hungarian operating unit, Studia Universitatis Economics Series, „Vasile Goldiș” Western University of Arad

14. Selim, A., Ashour, A., Bontis, N., (2004), Intellectual Capital in Egyptian Software Firms, The Learning Organization: An International Journal, vol. 11, no. 4/5, pp. 332-346

15. Sharabati, A.A.A., NajiJawad, S. Bontis, N., (2010), Intellectual Capital and Business Performance in the Pharmaceutical Sector of Jordan, Management Decision, 48(1), pp. 105-131

16. Starovic, D., Marr, B., (2004), Understanding Corporate Value: Managing and Reporting Intellectual Capital. The Chartered Institute of Management Accountants (CIMA) and Cranfield University, London

http://www.cimaglobal.com/Documents/ImportedDocuments/intellectualcapital.pd 17. Steward, T.A., (1999), Intellectual capital. The new wealth of organizations, Nicholas Brealey Publishing, London

18. Sveiby, K.E., (1997), The new organizational wealth: Managing \& measuring knowledge-based assets, Berrett-Koehler Publishers, San Francisco

19. Ting, I.W.K., Lean, H.H., (2009), Intellectual Capital Performance of Financial Institutions in Malaysia. Journal of Intellectual Capital, 10(4), pp. 588-599

20. Trandafir R.A., (2015), The Economic Value Added (EVA) - A measurement indicator of the value creation within a company from the Romanian seaside hotel industry, Annals of the "Constantin Brâncuși" University of Târgu Jiu, Economy Series, Issue 1, vol. I / 2015 